\title{
INDEX
}

Note: 'n.' after a page number indicates the number of a note on that page.

Aachen 4, 43, 129, 140, 142, 160, 162, 174, 182 n.261, 185, 210, 223, 240 n.44, 245, 254 n.121, 261

Abodrites 240, 258 n. 140

Adalard, bishop of Verona 228

Adalard, son of dux Henry 221-2, 226-7

Adalbero, bishop of Augsburg 2, 7, 9, $16,39,48-9,61-2,198$

Adalbero, bishop of Metz 239, 245, 254-5, 263

Adalbert, count of Metz 247

Adalbert, son of Berengar II 253, 262-70

Adalbert, son of dux Henry 221-2, 226-7, 229-31, 233

Adalbert of Magdeburg, as missionary 261, 263, 269

Adaldag, archbishop of HamburgBremen 241, 260, 264, 267

Adalelm, Odo's uncle 214

Adalgis of Benevento 52, 165-7

Adalhard, count of Metz 186

Adalung, count 219

Adelaide, queen 179, 215

Adelheid, empress 251-4, 257 n.135, 262 n.169, 269 n.206

Ado of Vienne, historian 11-12, 14, 20, 23

Adventius, bishop of Metz 160

Aelius Pertinax, emperor 71

Ageltrude, queen 220 n. 447

Agilulf, king 99, 101

Alan, Breton leader 10, 35, 41, 173, 208-9

Alberic, count in Lotharingia 48, $189,214,220$
Alboin, king 88, 92, 93 nn. 256, 258

Albuin, Frankish noble 163

Alemannia 7, 53, 56, 59, 99, 116, 121 , 144, 175, 177, 183, 193, 196, 198, 231-4, 238-40, 250, 256, 267

Alewic, abbot of Reichenau 259

Alsace 55, 177 n.236, 234, 237-8, 243, 253-4, 270

Altfrid, bishop of Hildesheim 162

Altötting 182, 225

Altrip 3

Anastasius I, emperor 26, 85

Anastasius II, emperor 22, 114-15, 116 n.398

Andernach, battle 175-6

Andlau 196 n.333

Angelfredus, patriarch of Aquileia 264

Angers, siege 168-9

Anglo-Saxons see England

Annales Regni Francorum see Royal Frankish Annals

Anno, bishop of Worms 251

Ansbald, abbot of Prüm 4, 35-6, 40, 136,194

Ansgard, queen 179

Antoninus Pius, emperor 70

Aquitaine 86, 98, 102, 116-17, 121, 133-4, 152-3, 214-16, 219

Arcadius, emperor 81-3

Arn, bishop of Würzburg 215

Arnold, count in Bavaria 255

Arnstadt 257, 258 n.141

Arnulf, bishop of Metz 17, 43, 101-2, 107, 182-3

Arnulf, count 211

Arnulf, dux of Bavaria 232, 233 n.9, 
234, 242

Arnulf of Carinthia, king of east

Francia and emperor 6, 34, 42, $48,53,182-3,197-8,200-1$, 206-7, 210-13, 215-25

Arras 86, 145 n.99, 181, 210 n.400, 227

Arsenius, papal legate 143-5

Artald, archbishop of Rheims 249

Askericus, bishop of Paris 195, 224

Asolf, abbot of St-Maximin 270-1

Asselt, siege 184-7, 190

assemblies 121, 138, 146, 158, 166, 196-7, 210, 214, 216-17, 219, 221, 224, 230-1, 247, 253, 258-9, 271

Astronomer, historian 42

Atto, count of Lecco 267

Augsburg 77, 144, 253, 272

Augustine of Hippo 13-14, 25, 78, 82-3, 116, 197 n.336

Aurelian, archbishop of Lyon 180

Aurelian, emperor 75

Aurelius Alexander, emperor 72

Authari, king 95, 97, 99

Azo, papal legate 260, 265, 266 n. 187,268

Babenberg 226, 230, 270

Babenbergers 215 n.424, 222 n.453, 227 n.479, 229 n.490, 261 n. 162

see also Adalard, son of $d u x$ Henry; Adalbert, son of dux Henry; Henry, dux, east Frankish general; Henry, son of dux Henry; Poppo dux of the Thuringians

Baldwin I of Flanders 130

Baldwin II of Flanders 130, 227

Baltram, bishop of Strasbourg 231 baptism see conversion

Bavaria 97, 108, 113, 116, 121, $124-5,161,177,182-3,186-7$, 198, 211-12, 216, 228, 232-6, 242, 248, 251, 253-6, 258, 261, 265
Bede, historian 11-14, 19-23

Belecke 242

Belisarius, Byzantine general 87-8

Beltheim 34, 219

Benedict, bishop of Metz 239

Benedict V, pope 265-7

Benevento 105, 111,142, 155, 165-7

Beneventum see Benevento

Berengar I, king 199-200, 223, 228

Berengar II, king 251-3, 258, 260-3, 265-70

Bergamo 217

Bernard (or Werner), count in the Wormsgau 233

Bernard, son of Bernard of Italy 130

Bernard, son of Charles the Fat 197-8

Bernard of Italy, king 129-30

Bernarius 37-8, 189

Bertha, queen 253

Bertold, count in Alemannia 233 n.9, 234

Bertold, dux in Bavaria, son of Arnulf of Bavaria 243 n.58, 247 n.87, 248, 255 n. 125

Bertrada, founder of Prüm 4, 13 n.50, 127 n.20

Bertrada, queen 4, 127 n.20, 128

Bertulf, archbishop of Trier 160, 186,188

Betuwe 192-3

Boethius 15, 87

Bohemians 177, 207, 239, 250

Boleslaw, Bohemian leader 250

Bonn 185, 212, 237, 246

Boris-Michael, Bulgar king 44-5, 157-8

Boso, count in Italy and brother of Theutberga 143-4

Boso, count of Vienne and king 39-40, 177-80, 217, 220, 228

Bratislava, battle 46, 232

Breisach 244, 255

Brennus 220

Bretons see Brittany

Brissarthe, battle 38, 153-4

Brittany 5, 9, 31, 33-5, 38, 40, 46-7, 
110 n.360, 130, 133, 136-9,

$153,168-73,205,208-10$

Brun, archbishop of Cologne 255-6, 259, 267, 269

Brunhild, queen 90-2, 99, 100-1

Bulgars 108, 116 n.399, 157-8, 205

Burchard, abbot of St-Gall 259

Burchard, a Saxon 250

Burchard, dux in Alemannia 238-9, 268

Burchard, dux in Thuringia 10, 215, 232 n. 2

Burchard of Worms 7

Burgundy 86, 99, 109, 179-80, 201, 217

\section{Camerino 265}

Campania 75, 92, 105, 111, 165, 269

Capua 34, 165, 167 n.192

Carloman, king 128

Carloman, mayor of the palace 32-3, $45,121,122-4$

Carloman, son of Charles the Bald $45,163-4$

Carloman, son of Louis the German see Karlmann of Bavaria

Carloman II, king of west Francia 39, 179-81, 187-90

Carus, emperor 76

Charibert, king 91

Charlemagne, emperor 1, 2, 43, 128, 129, 197

Charles, son of Charles the Bald 52, 163

Charles III the Fat, emperor 1, 5, 42, $45,174-5,177,183-4,186-7$, 190-9, 218, 226

Charles III the Straightforward, king of west Francia 6, 31, 48, 51,130 n.30, 170 n.203, 179, 215-17, 219, 222-3, 236-8

Charles Martel, mayor of the palace 1, 3, 22, 23, 27, 28, 43, 113, $115,116,117,118,121$

Charles of Provence, king 133-5

Charles the Bald, king of west

Francia and emperor 4, 17,

$$
\begin{aligned}
& 32-3,45,52,131-3,135-9, \\
& 145,151-3,160-4,168-9, \\
& 173-9
\end{aligned}
$$

Chèvremont 243, 244 nn.65, 69

Chiemsee 218

Childebert I, king 88-90

Childebert II, king 95-8

Chilperic I, king 90-4, 98

Claudius, emperor 65-6

Claudius, another emperor 75

Claudius of Turin, historian 11-12

Clodomer, king 90

Clothar I, king 89-90

Clothar II, king 98-9, 101, 104

Clovis, king 26, 28, 86

Cologne 100, 107, 109, 160-2, 174, 176, 185, 192, 209-10, 254, 258-9, 267, 269

Compiègne 138, 227

Conrad, count 152-3, 201

Conrad, count of Paris 180

Conrad I, king of east Francia 53, 228, 233-5

Conradines 53, 189 n.303, 215 n.424, 229 n. 490,230 n. 492,244 n.67 see also Conrad I, king of east Francia; Conrad the Elder, father of Conrad I; Eberhard, brother of Conrad the Elder; Eberhard, dux of Franconia, Gebhard, dux in Lotharingia; Herman, son of Gebhard, dux in Alemannia; Rudolf of Würzburg; Udo, son of Gebhard

Conrad 'Kurzbold', son of Eberhard (brother of Conrad the Elder) 233, 244, 249

Conrad son of Gebhard 250

Conrad the Elder, father of Conrad I 215, 224, 228-30, 233

Conrad the Red, dux in Lotharingia $247-9,252-7$

Constans II, emperor 104, 105

Constantine I, emperor 78

Constantine III, emperor 103

Constantine IV, emperor 106 
Constantinople 83-5, 88, 92, 94, 96, 100, 102-3, 105-7, 109, 112-13, 116-17, 260, 272

Constantius, emperor 79

conversion $64,67,73,86,95-6,101$, 103, 107, 157-8, 187, 240, 260

Corsica 167, 263-4, 267

Corvey 245

councils see synods

Coutances 208

Cross, True 78, 100-1, 111

Dagobert I, king 94, 101-4, 106-10

Danes 128, 191, 240

Decius, emperor 73

De harmonica institutione 6

Denis, St 127-8

De synodalibus causis 7, 10, 36

Deutz 161

Diocletian, emperor 76, 77

Domitian, emperor 68

Dortmund 254

Drogo, bishop of Metz 42, 134

Drogo, bishop of Toul 231

Duisburg 37, 191, 239, 247

Duodo, palace chaplain 266-7

Durfos 222, 224

Dyle, battle 34, 211-12

Eberhard, archbishop of Sens 202

Eberhard, brother of Conrad the Elder 226-7

Eberhard, count of Lahngau 270

Eberhard, dux of Franconia and brother of Conrad I 57, 240, 242-4

Eberhard Saxo, count in Hamaland 36-7, 40, 184, 193, 223

Eberhard, son of Arnulf of Bavaria 242-3

Ebo, archbishop of Rheims 131

Ebolus, abbot of St-Denis 214, 216

Echternach 164

Edith, queen 240, 245, 249

Egino, count 230-1, 232 n.2

Eigil, abbot of Prüm 3, 133, 136

Einhard, bishop of Speyer 233
Ekkehard, abbot of Reichenau 259

Emma, east Frankish queen 174

Emma II, west Frankish queen 269

Engelram, count in Frisia 37, 38, 189

Engiltrude, ex-wife of Count Boso 141 n.82, 143-5, 213 n.411

England 96, 101, 104-5, 108, 114, 240

Erchanbert, abbot of Wissembourg 267, 269

Erchanbold, bishop of Strasbourg 268

Erchangar, count in Alemannia 233 n.9, 234

Eresburg 245

Erfurt 241

Erispoë, Breton leader 137 n.65, 138-9, 153, 170 n.205, 173

Ermengard, empress 133, 253 n.119

Erstein 253

Eusebius of Caesarea, historian 11

Evesa, mother of Eberhard 26, 184

Farabert, abbot of Prüm 194, 213

Flamersheim 163

Flörchingen 223

Folcmar, archbishop of Cologne 269

Forchheim 225

Formosus, pope 220

Franco, bishop of Liège 160-1, 223

Frankfurt 174-5, 185, 194 n.321, 216, 240 n.44, 246, 250, 253, 271

Frechulf of Lisieux, historian 11, 12,17

Fredegund, queen 91, 94, 98

Frederick, archbishop of Mainz 241, 244-6, 252-7, 259

Frederick, archbishop of Salzburg 259

Friderada 189

Frisia 37-8, 111, 115, 126, 177, 187, 191-2

Fritzlar 229, 236 n.19

Fulda 207, 234-5, 242, 245-6

Fulk, archbishop of Rheims 10, 34, $52,215,219,227-8$ 
Gaius, emperor 65

Gallus, emperor 74

Garda 262, 264

Gardulf, count in Frisia 192

Gauzbert, count in Aquitaine 136

Gauzbert, Ranulf's brother 214

Gauzlin of St-Denis 180 n.255, 181 n.258, 191 n.309, 194 n.324, 195

Gebhard, dux in Lotharingia 224, 226-30, 232

Geilo, abbot of Wissembourg 259-60

Gerard, count in Lotharingia 6, $47-50,188$ n.295, 213, 221, 225-6, 228-9, 231

Gerberga, daughter of Berengar II 267

Gerberga, wife of Giselbert then Louis IV 239, 244 n.68, 245, 255 n. 127,267

Germanus, St 165

Gero, marchio 264 n.182, 269

Gerric, abbot of Wissembourg 260, 266-7

Gerulf, count in Frisia 192, 223

Gesta Dagoberti 19, 26-7

Geul, battle 34, 210-11

Gewelesdorf 34

Gisela, daughter of Berengar II 267

Gisela, daughter of Lothar II 187, 191-3

Giselbert, dux in Lotharingia 237, 239, 243-4, 245 n.70, 246 n.77, 247 n.86, 259 n. 153

Godafrid, Viking leader 36-7, 184, 187, 191-3

Godfrid, bishop of Speyer 262

Godfrid, dux in Lotharingia 266

Gondreville 190

Gordian, emperor 73

Gralo, abbot of St-Gall 259

Gratian, emperor 81

Gregory I the Great, pope 7, 96, 156

Grimoald, Lombard king 104-8

Gunther, abbot of Hersfeld 260

Gunther, archbishop of Cologne 44, 139-43
Guntram, Frankish king 26, 90, 93, 97-9

Guy, bishop of Modena 268

Guy, son of Berengar II 262, 268

Guy of Spoleto, Italian king 199-200, 218, 220

Hadamar, abbot of Fulda 258

Hadrian, emperor 70

Hadrian II, pope 43, 156, 158-60, 164

Hagano, abbot of Hersfeld 260

Hagano, papal legate 141-2

Haicho, abbot of Fulda 237

Hartbert, bishop of Chur 250

Hasting, Viking leader 154, 172-3

Hatto, abbot of Fulda 258, 262

Hatto, archbishop of Mainz 7, 39, 212, 224, 233

Heimsheim 267

Helen, queen of the Rus' 260

Henry, archbishop of Trier 258, 264, 266

Henry, brother of Otto I 242-6, 251-6, 258

Henry, dux, east Frankish general 189 n.298, 191-5, 221

Henry, son of dux Henry 221-2, 226-7

Henry I, east Frankish king 53-4, 235-41

Henry the Quarrelsome, dux of Bavaria 258

Heracleonas, emperor 102

Heraclius, emperor 101

Herbert I, count of Vermandois 10, 130,215

Herbert II, count of Vermandois 238, 249

heresy, heretics 24-6, 28, 79, 82-6, 102, 103-4, 106, 109, 112, 114, 117,142

Heriger, archbishop of Mainz 233, 238

Herispich 192

Heriveus, archbishop of Rheims 228

Hermann, archbishop of Cologne 209, 237 
Hermann, son of Gebhard, dux in

Alemannia 232, 239, 248, 250

Herod 62-3, 65

Herold, archbishop of Salzburg 256, 259

Hersfeld 235

Herstal 162

Hildebert, abbot of Fulda and archbishop of Mainz 237-8, 241

Hildegard, daughter of Louis the Younger 218

Hildesheim 242

Hilduin, archbishop of Cologne 160-2

Hilduin of St-Denis, abbot 41

Hincmar of Rheims, historian 52

Honorius, emperor 82

Hubert, brother of Theutberga 135, 141,144 n.92, 145 n.97, 152, 153 n.132, 189 n.298

Hugh, abbot of St-Maximin and bishop of Liège 241,248

Hugh, archbishop of Rheims 249 Hugh, son of Louis the Younger 181 Hugh of Lotharingia, son of Lothar II $5,32,37,43,46,188-9$, 191-4

Hugh the Abbot 153 n.132, 154-5, 180, 181 n.259, 190, 191 n.309, 195,201

Hugh 'the Great', count of Tours 248 Hungarians 46-7, 202-6, 218, 226, 232-4, 237-8, 240, 243, 247, 256-7

Ida, daughter of dux Hermann 249

Immo, count in Lotharingia 247

Inden 185

Ingelheim 130-1, 246, 249, 254, 259, 267

Irmingarde, daughter of Louis II 177,217

Isidore of Seville 11

Italy see Benevento; Lombards; Louis II of Italy; Rome

Jengland, battle 33, 47, 136-8
Jerome, historian 11, 13, 31

John VIII, pope 164, 166-7, 173, 177,184

John XII, pope $262-5$

John XIII, pope 268-72

John the deacon, papal legate 260, 265, 266 n. 187

Jovian, emperor 80

Judicael, Breton leader 35, 173, 208-9

Judith, empress 17, 131

Judith, wife of dux Henry 255

Julian, emperor 80, 164

Jülich 185

Justin, historian 15, 30, 46

Justin I, emperor $86-7$

Justin II, emperor 89

Justinian, emperor $87-8$

Justinian II, emperor 109-10, 112-13

Karlmann of Bavaria, east Frankish king 174-5, 177, 182, 218

Koblenz 192

Lago Maggiore 262

Lake Como 262, 267

Lambert, count of Nantes 136

Lambert, Italian king 218, 220

Lannesdorf 212

Lantward, bishop of Minden 264

Laon 214, 219, 222 n.455, 248

Lausitzer 264

Lech, battle 54, 257

Leo (Leontios), emperor 110-12

Leo II, emperor 84

Leo III, emperor 116-18

Leo VIII, pope 264-6, 268

Leuven 191, 194

Liber Historiae Francorum 19, 23 , 26-7

Liber Pontificalis 20-1, 23

Libutius, missionary 260-1

Liège 112, 185, 210

Liudolf, son of Otto I 249-52, 254-9

Liutbert, archbishop of Mainz 161-2, 164 n.185, 197, 206 
Liutgard, daughter of Otto I 249, 255 Liutpold, dux of Bavaria 232

Liutpoldings 255 n. 125

see also Arnold, count in Bavaria; Arnulf, dux of Bavaria; Judith, wife of dux Henry; Liutpold, dux of Bavaria

Liutprand, Lombard king 113, 117 , 118

Liutprand of Cremona, historian 54, 56, 268

Liutward, bishop of Vercelli 196, 226 locusts $167-8$

Lombards 22, 25, 88-90, 92-6, 99, 101-2, 104-5, 107-11, 118 , 126, 178, 187, 217, 220, 226, 253, 268

Lorsch 39, 174, 181, 186, 217, 245, 258

Lothar I, king of middle Francia and emperor 4, 5, 14, 32, 33, 39, 40, 41, 52, 129, 131-2, 133-4, 135,136

Lothar II, king of Lotharingia 5, 25, $27,30,39,43,44,45,133-4$, $135,139-52,155-60$

Lothar, king of Italy 251

Lothar, king of west Francia 267, 269

Lotharingia/Lotharingians 2, 5, 6, $37,43-4,48,53,59,132$ n.40, $132,134,161-2,174,177,181$, 189 n.298, 191, 194, 201, 210, 216-17, 229, 234, 237-9, 241, 243-7, 254-6, 261, 266, 269,

Louis, son of Louis the Younger 186

Louis II of Italy, emperor 34, 52, 133-4, 142, 155, 165-7, 170

Louis II the Stammerer, king of west Francia 163, 178-9

Louis III, king of west Francia 39, $179-81,187-8$

Louis IV d'Outremer, king of west Francia 238, 243-5, 248-9

Louis IV the Child, king of east Francia 6-7, 18, 42, 45-7, 51, $53,58,225,230-1,233$
Louis the Blind of Provence, king of Italy 39, 180 n.257, 217-18, 220, 223, 228

Louis the German, king of east Francia 45, 52, 131-2, 136, $144,151-2,157,161-3,164$ n. 185,174

Louis the Pious, emperor 41-2, 52, 129-31, 134, 245

Louis the Younger, king of east Francia 174-7, 181, 183-6

Lucania 165, 271

Lucius Commodus, emperor 71

Ludelmus, bishop of Toul 220, 231

Lupus, abbot of Ferrières 17, 33, 35

Lyon $71,81,180$

Maastricht 185, 210, 247

Magdeburg 55, 249, 252 n.114, 253 n. 115,262 n. 169

Magyars see Hungarians

Maienfeld 176, 214 n.420, 267 n.192

Mainz 132 n.39, 174 n.223, 237, 254-5, 257 n.134, 259

Marcian, emperor 83

Marcus Aurelius, emperor 70, 71

Marcward, abbot of Prüm 13, 32-3, 130

Marinus, bishop of Sutri 268

Marinus, papal legate 249

martyrdoms 67-80, 85, 100, 119-20

Matfrid, count in Lotharingia 6, 47-50, 188 ก.295, 213, 221 , 225-6, 228-9, 231, 247

Matfridings 6, 47-50, 188 n.295, 216 n.431, 229 n. 487 see also Gerard; Matfrid; Richar Mathilda, daughter of Liudolf 250 Mathilda, east Frankish queen 267

Maurice, emperor 95-6, 99

Maximinus, emperor 73

Meersen 162-3

Megingoz, count in Lotharingia 48, 188 n.295, 189 n.299, 214-15, 216 n. $431,220,221$ n. 450,229 n. 487,249 n.94 
Meginhard, count in Hamaland 36, 223

Meginhard, father of Eberhard 36, 184

Metz 4, 90, 109, 131, 140, 142, 160, 186, 213 n.411, 221, 231, 237, 239, 244-5

Monte Cassino 32-3, 110, 122-4

Moosburg 183

Moravians 136, 177, 205, 207, 218

Morman, Breton leader 130

Muslims see Saracens

Nantes 36, 133, 136 n.63, 137 n.64, 153,173 n.216

Nero, emperor 67

Nerva, emperor 69

Neuss 185

Nicephorous II, emperor 271-2

Nicholas I, pope 24, 43, 141-51, 155-6, 159, 189

Nijmegen 29, 184, 223

Nominoë, Breton leader 35, 130, 137 n. 64,138

Northmen 5, 133, 153-4, 168-73, 181, 184-96, 201-2, 206, 208-12

Notker of St-Gall, historian 31

oaths $115,121,126,139,143-6,151$, $158,165-7,175,179-81,191$, 223, 229, 256, 265, 270

Octavian Augustus 62

Oda, Zwentibald's wife 22 1, 226

Odacar, count in Lotharingia 221-2, 224

Odilbald, bishop of Utrecht 225

Odo, count of Paris and king of west Francia 4 n.6, 6, 34, 39, 41, 51, 130 n.30, 154-5, 195, 200, 214-17, 219, 222

Oeren 221, 229

Orbe 153

Orosius, historian 17

Otbert, bishop of Strasbourg 231, 234

Otbert, marchio 260
Otger, bishop of Speyer 262, 264-5, 268

Otto, dux in Lotharingia 246-7

Otto, son of Liudolf 257

Otto I, emperor 54-5, 57-8, 239, 241-72

Otto II, emperor $55,56,58,258$, 261-2, 267, 271-2

Otto the Illustrious, father of Henry I 221,233

Pacsweten, Breton leader 35, 170-1, 173

Paris, siege 194-6, 201, 206, 208

Paul, saint 24, 64, 66-7, 127-8, 132, 144,148

Paul the Deacon, historian 19, 21-4, 27-8, 30, 46

Pavia 178, 252, 261-3, 267

Persians 25, 87, 93, 100-1, 103

Petchenegs 204-5

Peter, saint 24, 65-8, 127-8, 132, 144,148

Pfeddersheim 237

Philip, emperor 73

Philippicus, emperor 112-14

Phineas 147

Phocas, emperor 100

Piacenza 160, 217

Pippin, son of Bernard of Italy 130, 215

Pippin I of Aquitaine, king 42, 134

Pippin I of Italy, king 130

Pippin II of Aquitaine, king 133-4

Pippin II, dux 102, 113

Pippin III, king 1, 117-18, 121-2, $124,125,128$

Pippin the Hunchback, son of Charlemagne 32

Poppo, dux of the Thuringians 206, 215

Poppo I, bishop of Würzburg 261

Poppo II, bishop of Würzburg 261

Pressburg see Bratislava

Probus, emperor 76

Prüm 185, 194, 210, 212, 223 
Ranulf, count in Aquitaine 214

Ranulf, count of Poitiers 153-4, 168

Raoul, king 238

Rastiz, Moravian leader 136

Ratbod, archbishop of Trier 6-7, 188

Ratbod, bishop of Utrecht 225

Ravenna 68, 83-4, 86, 92, 116-17, 184 n. $275,271-2$

Regensburg 183, 186, 225 n.469, 255-6, 261

Reginar, count and standard-bearer 176

Reginar, count in Lotharingia 48, 51, 222, 224

Reginar III, count in Lotharingia 259

Reginold, bishop of Eichstätt 269

Reichenau 198, 212, 237

Rennes 171

Rethel 214

Revelatio Stephani Papae ('Vision of

Pope Stephen') 13 n.50, 28, 30, $42,126-8$

Rheims 86, 90, 215, 248-9, 256 n.133 Richar, abbot of Prüm and bishop of Liège 47-8, 50, 213, 247-8

Richard, count 39-40

Richgard, empress 196

Richildis, queen of west Francia 177

Richwin, count of Verdun 37-8, 189, 246 n. 77

Rihgowo, bishop of Worms 251

Robert, archbishop of Trier 239, 247, 251,258

Robert, bishop of Metz 188

Robert, count in Lotharingia 188

Robert, count of Tours and king 154-5, 216, 236, 248

Robertians see Odo, Robert the Strong, Robert count of Tours

Robert the Strong, count of Angers 38-9, 41, 138, 153-4, 168, 195, 200

Rodoald, papal legate 141-2

Roger, archbishop of Trier 237, 239

Romanus I, emperor 260

Romanus II, emperor 272
Rome 1, 23-6, 28, 32, 43, 54, 56-8, $66-70,75-8,80-2,85,88,92$, $94,99,105-6,112,115,117$, $122,132,141-3,145,156$, 158, 160, 166-7, 173, 177, 184, 203, 209, 218, 220, 223, 262-8, 271-2

Rotfred 269-70

Royal Frankish Annals 2, 16-17, 22, 29,42

Rudolf, bishop of Würzburg and brother of Conrad the Elder 215, 221-2, 226-7, 232 n.2

Rudolf, count of Cambrai 130

Rudolf I of Burgundy, king 201, 217-18

Rudolf II of Burgundy, king 242, 251

Rümlingen 256

Ruodhard, bishop of Strasbourg 244-5, 251

Rus' 55, 260-1, 263, 269

Saalfeld 252

St-Alban, Mainz 164 n.185, 259-60

St-Denis 19, 30, 41, 110, 178, 187, 190, 216,222

St-Gall 193, 209, 242

St-Goar 48, 98, 224

St-Lô 208

St-Maurice d'Agaune 201, 217

St-Maximin, Trier 48, 55, 214 n.420, 215 n.423, 228-9, 231 n.498, 241, 246, 251, 259, 261, 270

St-Médard 133, 195

St-Vaast 3, 34, 130 n.30, 145 n.99, 181,227

Salomon, Breton leader 35, 39, 40-1, 153, 169-72

Salomon II, bishop of Constance 209

Salomon III, bishop of Constance 209, 234

Samnium 165

San Giulio 262

San Leo 262-3, 265, 268 n.198

Saracens 45, 105, 107, 109, 115-18, 155

Saucourt, battle 188 
Saxony 53, 55, 121, 124-5, 176, 192, 232, 234, 245, 252, 254, 256, 260-1, 267-8, 270-1

Schwalfeld 177

Scythians 46-7, 202-4

Sens 152, 201-2, 206

Severus, emperor 71, 72

Sigibert I, king 90-1

Sigifrid, Viking leader 184, 187

Sigolf, bishop of Piacenza 270

Sinzig 192

Slavs 45, 108, 136, 177, 182, 207,

$211,215,218,236,241,257$,

259-60, 264, 268

see also Abodrites; Bohemians;

Lausitzer; Moravians; Vucrani

Soissons 90, 98, 125, 133, 195, 236

Sophia, empress 93, 95

Spain 65, 86, 88-90, 95, 96, 103, 108, 117

Spoleto 265, 271

Starkand, bishop of Eichstätt 269

Stavelot-Malmedy 185

Stephen, brother of Alberic 189

Stephen II, pope 126-8

Stephen, Lotharingian count and brother of Walaho 48, 188, 189 n.299, 220-1, 225-6

Strasbourg 231, 238

Sunderolt, archbishop of Mainz 206-7, 211

Swabia see Alemannia

synods 43, 78, 81, 103, 109, 112, 115, 131, 140-2, 218-19, 239, 241, 246, 249, 259, 264, 266, 271

Tacitus, emperor 75, 76

Tancrad, abbot of Prüm 130

Tassilo I of Bavaria 97

Thankmar, brother of Otto I 242 n. 57,245

Thegan, historian 41, 52

Theoderic, archbishop of Trier 269

Theoderic, bishop of Metz 263, 269

Theodosius I, emperor 81

Theodosius II, emperor 83

Theodosius III, emperor 115
Theophanu 272 n.226

Theres 227 n.479, 230

Theudebert I, Frankish king 89-90

Theudebert II, Frankish king 98-101

Theuderic II, Frankish king 98-101

Theutbald, son of Hubert 189

Theutberga, queen 43, 135, 139-41, $143,145-50,152$

Theutgaud, archbishop of Trier 44, 139-40, 142-3

Thietmar, Saxon count 260

Thiméon, battle 52, 181

Thionville 126, 225, 245

Thuringia 26, 87, 90, 124, 176-7, $187,206,215,232-4,236,241$

Tiberius III, emperor 111

Tiberius Constantine, emperor 93-5

Tiberius, emperor 63-4

Titus, emperor 68

Tongres 79, 112, 185

Toul 206

Trajan, emperor 69

Tribur 197, 218, 230

Trier 4, 6-7, 13, 16, 20, 31, 38, 41, $47-8,55-6,78-9,83-4,89,98$, 160, 186, 210, 214 n.420, 221 , 228-9

see also $\mathrm{St}-\mathrm{Maximin}$

Troyes 206

Udo, bishop of Strasbourg 251, 268

Udo, count of Maienfeld 267, 270

Udo, son of Gebhard 232, 244, 247, 250

Unni, archbishop of HamburgBremen 241

Valens, emperor $80-1$

Valentinian, emperor 80

Val Travaglia 262

Verdun 38, 83-4, 132, 206

Verona 92, 228, 253, 272

Vespasian, emperor 67-8

Vikings see Northmen

Villance 39

Vivian, count of Tours 136 
Vucrani 241

Wala, bishop of Metz 186

Walaho, brother of Stephen 188 n. 295

Waldo, bishop of Chur 250

Waldo, bishop of Como 260, 267, 270

Waldrada, mistress or wife of Lothar II 139-41, 143, 145-51, 159

Waltbert, archbishop of Milan 260

Walter, archbishop of Sens 202

Walter, bishop of Orléans 202

Waltgar, cousin of Odo 214

Waltgar the Frisian 223

Wandalbert of Prüm 13-14

Wanger, lover of Engiltrude 144 warfare see Andernach; Angers;

Asselt; Bratislava; Brissarthe; Brittany; Dyle; Geul;

Hungarians; Jengland; Lech; Northmen; Paris; Saucourt; Thiméon

Weilburg 230

Wichmann, Saxon noble 242 n.57, 245, 258, 260 n.156

Widukind of Corvey, historian 54, 56

Wigbert, count in Lotharingia 188-9
Wigfrid, archbishop of Cologne 237, 255

Wikerus, abbot of St-Maximin 270

Wikerus, archbishop of Mainz 259

Willa, queen 261-2, 265, 270

William, archbishop of Mainz 55, 239, 257, 259, 261, 263, 267, 271

Willibert, archbishop of Cologne 161-2, 192-3, 209

Winemarus, follower of Baldwin II 227-8

Wissembourg 55, 259

Witgar, bishop of Augsburg 198

Witgar, bishop of Metz 237

Worms 216-17, 219, 221, 250, 261, 267, 270-1

Wrhwant, Breton leader 15, 35, 44, 170-3

Zedechias, doctor 178

Zeno, emperor 85

Zülpich 87, 100, 185

Zwentibald, king of Lotharingia 6, 10, 38, 48, 51, 130 n.30, 193, 201, 215, 217, 219, 221-6

Zwentibald, Moravian leader 207, 218 